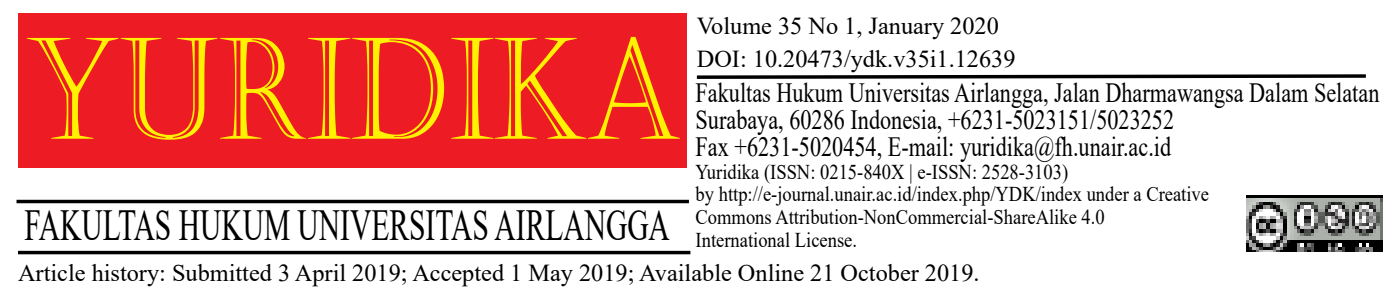

\title{
Juridical Analysis on Entrepreneurs' Obligation of Effort to Prevent Termination of Employment
}

\author{
Budi Santoso \\ budi.santoso@ub.ac.id \\ Univeritas Brawijaya
}

\begin{abstract}
This article aims to analyze the applicability of the employer's duty of care to prevent employment termination based on Article 15(1) Act No. 13 of 2003 on Labour, questioning if those obligations applied to all grounds and reasons resulting in termination of employment. To answer the objectives, this legal research uses the method of legislative approach by analyzing the available legal sources through systematic interpretation and legal argumentations. Relying on the result of the discussion, a conclusion is reached that employer's obligation of effort to prevent termination employment, as regulated under Article 151(1) UUK, is excluded when the employee is unable to perform its obligated duty after six months because he/she is entangled in criminal proceedings. If the Court decides the proceedings before the six months term ends and the employee is found to be guilty, then he/she is no longer the responsibility of the employer.
\end{abstract}

Keywords: Duty of Care to Prevent Employment-Termination; Employer Obligation; Reasons for Termination.

\section{Introduction}

An employee undertaking duty based on the instruction of their employer is a manifestation of employment relation between both. This relation is borne out of employment agreement. The relation is interdependent, as the employer needs the employee in pursuit of profits and the employee needs the employer to earn a salary based on the duty they had finished. The salary is used by the employee to fulfill their life necessities and amenabilities. Hence, the cooperation between the parties in the working regulation is an integral part of the employment relation. ${ }^{1}$

\footnotetext{
${ }^{1}$ Robert C. Byrd, 'Employment as A Relational Contract' (2005) 8 Journal of Labor and Employment Law.[54].
} 
Employment relation terms and conditions can be agreed upon by the parties dependent on their necessities and field of work. In Indonesian Labour Law, specifically in Article 56 Legislation No. 13 of 2003 on Labour (hereinafter, "UUK"), employment relation born out of an agreement can be in effect for a certain period of time or uncertain period of time. A certain period of time refers to the situation when the relation is based on a specified length of time or, is dependent on how long the task can be finished.

Employment relation on certain period time commonly ceases when the time specified agreed on the agreement is over. Yet, based on Article 62 UUK, when the employment relations terminated unilaterally by one party before the agreed time, then the party (that terminates the agreement) is obligated to pay for damages in the amount equivalent to what the other party expects to earn should have the agreement is not terminated. This applies to both the employer and employee respectively. The terms above differs for the employment relation with uncertain period of time. If the employee terminate the relation unilaterally, the employee is not in obligation to compensate. Relying on Article 162 (3) of UUK, the employee is obligated to: (1) sent a written plea no later than thirty days before resignation, (2) is not binded to the Government, and (3) must still carried his or her duty normally until the resignation date.

On the contrary, in the event the employment relation termination of an uncertain period of time done by the employer, then the latter must provide a specific reason and to conduct in a special procedure previous to the termination. The employee is to be treated fairly in the event the employer decides to terminate him or her. ${ }^{2}$ For instance, if the employee is terminated because the employee refused to be mutated, it must be sought whether the mutation requested by the employer is indeed objective, necessary for the interest of both the company and the employee, fair, and not discriminative. ${ }^{3}$ In the universal context, ILO Convention

\footnotetext{
2 A.C.L Davies, Perspectives on Labour Law (Cambridge University Press 2004).[159].

${ }^{3}$ Deden Muhamad Surya, 'Pemutusan Hubungan Kerja Akibat Menolak Mutasi Ditinjau Dari Perspektif Asas Kepastian Hukum Dan Asas Keadilan’ (2018) 2 Jurnal Wawasan Yuridika.[185].
} 
No. 158 of 1982 on Termination on Employment based on the Employer Initiatives (further mentioned as, "Termination of Employment Convention") has regulated a requirement that every employer must provide a valid reason to the employee and that the employee must have the right to defend his or herself. ${ }^{4}$ The requirement supra is adopted to Indonesian Labour Act. For example, Article 153 of UUK prohibits the employer to terminate their employment relation based on invalid reasons such as, because the employee gets married, a woman employee is pregnant, or the employee has established a labour union. Termination such as this is null and void. The legal consequence was that the employer is obligated to hire the employee again. In the meantime, for a procedural reason, Article 151 UUK obligate the employer, employee, and the Government to endeavor in the best of their abilities to prevent any employment termination. This prevention can be pursued through a set of positive activities such as regulation on working days and hours, improvement on ways of working, or giving training [or workshop] to the employee. This regulation reflects the way issues on termination of employment are not independent of the issues on labour rights, in a sense that an employee, is after all a human that is entitled to fairness. ${ }^{5}$

However, stipulation on Article 151 (1) UUK, did not firmly state whether the obligation for the employer to conduct positive activities before terminating the relation is applicable to all categories of reason or only at those of specific reason justifying the termination. As was known, UUK did not categorised the employer reason for employment-termination, but generally, the reasons are divided into three: (1) reasons pertinent to the inability [incompetence] of the employee, (2) reasons pertinent to the employee indiscipline, and (3) reasons pertinent to the company operational interests. ${ }^{6}$ These three categories implicitly contained within UUK. Thus, this paper aims to analyse whether the obligation to prevent employment-

\footnotetext{
${ }^{4}$ Simon Deakin and Wanjiru Njoya, 'The Legal Framework of Employment Relations, Working Paper No. 349’ (2007).[12].

5 Bob Hepple, 'A Right to Work' (1981) 10 Industrial Law Journal.[66].

6 Article 4, ILO Convention No. 158 of 1982 on Termination of Employment.
} 
relation imposed to the employer, based on Article 151(1) UUK, is applied to all reasons of termination. For the interest of the discussion, this legal research uses the legislative approach by analyzing legal materials that have been collected through the library and the internet. This legal material will be analysed through systematic interpretation and legal argumentation.

\section{Protection for the Employee from Employment Relation Termination}

Philadelphia Declaration in 1944 stated that labour is not a commodity. ${ }^{7}$ The statement shows that while the employment-relation nature is subordinated, the employee is still entitled to fair treatment. The rights and interests of the employee must be given legal protection. ${ }^{8}$ Accordingly, in Indonesia, such recognition is then implemented on Article 28D (2) of the 1945 Constitution that stated: every person is entitled to occupation as well as to get an income and a fair and proper treatment in labor relations. The philosophical basis implies that the employee shall not be regarded only through the lense of economic-benefits, in a sense that their utility was only to earn profits for the employer, but, it shall also be regarded through the lense of human rights. Labour is not the same with machines, goods, or money. They must be treated humanely. Hence, although the employer owns the right to terminate employment-relation unilaterally, such right is limited. The employer must execute his or her intent fairly. This fairness is the form of protection for the employee from arbitrary action. This fairness manifest when: (1) the termination is followed by adequate and valid reason, (2) the employee is given severance pay, and (3) can be re-hired when the termination is found to be invalid.

The requirement that every employment-relation termination from the employer initiatives must be followed by valid reason is a form of employee protection from arbitrary treatment. The valid reason intended, supra, is assessed

\footnotetext{
7 Article 1(a), ILO Declaration of Philadelphia 1944 concerning the Aims and Purpose of the International Labour Organisation.

8 Mohammad Ilyas, 'Pengambilalihan Dan Penutupan Perusahaan Yang Berdampak Pada Perselisihan Pemutusan Hubungan Kerja Menurut Undang-Undang Nomor 13 Tahun 2003 Tentang Ketenagakerjaan' (2018) 3 Jurnal Ius Constituendum.[115].
} 
through legislations and is proved to be correct. As mentioned before, universally, Article 4 of ILO Convention on Termination of Employment regulates that employer employment-termination is valid when the pertinent employee is: (1) incompetence, (2) indiscipline, or (3) for the sake of the company operational interests. Meanwhile, Article 5 of the Convention firmly establish the prohibition for the employer to utilise invalid reasons to terminate employment-relation, such invalid reasons are: (1) because the employee is part of labour union, (2) because of pregnancy, (3) religion, (4) absence due to pregnancy, sickness, (4) marital status, or et cetera.

When the reason for termination is proven to be correct and in accordance with the law, the employer must pay compensation for the employee, if they possess permanent status. Article 156 (1) UUK divides the type of compensation into: (1) severance money, (2) appreciation money, (3) rights substitution money. Such rights include rights for annual leave and others deemed to be appropriate. The severance pay is intended to cover the cost of living the employee should have earned if he or she had not been terminated until they are employed once again. ${ }^{9}$ The amount of severance and appreciation money is determined from the length of time the employee had work and the type of reason for the termination. For instance, if the terminated employee had violated employment agreement (after the first, second, and third subsequent warnings) he or she is entitled for single severance payment pursuant to Article 156(2), single appreciation money pursuant to Article 156(3), and substitution of rights money pursuant to Article 156(4) of UUK.

On another hand, if the termination is proven to be invalid because the employee is terminated for untruth reason, the employer is obligated to rehire the pertinent employee and compensate all the money and rights he or she ought to receive.$^{10}$ For example, in the dispute between Sodikin Abdul Latif (employee) $v$. PT Bintang Mandiri Bersaudara (employer), the employee filed a claim against the employer as it had unilaterally terminate their employment-relation with no clear

\footnotetext{
9 Aloysius Uwiyono dkk, Asas-Asas Hukum Perburuhan (Rajagrafindo Persada 2014).[136]

${ }^{10}$ Article 153(2) and Article 155(1) Legislation No. 13 of 2003 on Labour.
} 
reason. The employee assessed the termination is made because of the employee position as the Head of Labour Union in the said company. In the proceedings at the Court of Industrial Relation on Manado District Court, the Judge evaluate that the termination by the defendant to be unreasonable and is procedurally incorrect. Therefore, the Judge decided that the termination is a breach against Legislation No. 13 of 2003 on Labour and Legislation No. 12 of 2000 on Labour Union. The Judge condemns the defendant to rehire the plaintiff ${ }^{11}$ and the decision is further reinforced through Supreme Court decision. ${ }^{12}$

Meanwhile, the employer ought to discuss beforehand, his or her plan to terminate the directed employee, ${ }^{13}$ as form of employee protection against arbitrariness. In the event the discussion ended futile, the employer cannot immediately seek the Court. There is a mediation procedure that must be fulfilled. As Ashgar Ali Ali Mohammed had said, dispute on industrial relation, including dispute on termination, ideally be settled through mediation. This was because mediation is a process of dispute settlement through collaborative, non confrontative, that ought to be carried in good faith. ${ }^{14}$ If the dispute can be settled by the equal parties, then a mutual agreement can be reached. The mutual agreement shall be made based on Article 1320 of Civil Code for it to be valid. ${ }^{15}$

When the obligation to conduct for discussion is not fulfilled by the employer, the request of permission for employment-termination shall be rejected by the Court. ${ }^{16}$ This was to give the employee a chance to defend his or her position. For example, in the dispute between Buntarmin and Tjatur Irianto v. PT Nestle Indonesia, the Court justified termination done by the employer as it had, previously, try to conduct mediation to settle their dispute. The termination was based on the

\footnotetext{
${ }_{11}$ Manado District Court of Industrial Relation Decision No. 22/G/2012/PHI.MDO.

12 Supreme Court Decision No. 658K/Pdt.Sus/2014.

${ }_{13}$ Article 151 (2), Legislation No. 13 of 2003 on Labour.

14 Ashgar Ali Ali Mohamed, 'Resolution of Industrial Disputes in New Zealand' (2012) 2 International Journal of Humanities and Social Science.[208].

15 Indi Nuroini, 'Penerapan Perjanjian Bersama Dalam Pemutusan Hubungan Kerja' (2015) 8 Jurnal Yudisial.[337].

${ }^{16}$ Article 152 (2), Legislation No. 13 of 2003 on Labour.
} 
reason that the employee had breached the company regulation and had ignored the first, second, and third letter of warning. ${ }^{17}$

\section{Obligation for the Employer to Prevent Employment-Termination}

UUK allows an employer to terminate his or her employee. But such right is limited by a procedural aspect and is determined by the validity of grounds used as reason, whether it was in accordance with the legislation. ${ }^{18}$ The procedural aspect means that the terminated employee is to be given the right to state his or her claim of defense. While as has been mentioned supra, valid grounds in accordance with legislation means that reason for termination by the employer can only be justified if, it is, based on reasons pertinent to employee: (1) inability [incompetence], (2) indiscipline, or (3) for the sake of the company operational interests. Reasons implicating or involving human rights is prohibited.

The employee's physical and cognitive inability is not stated explicitly within UUK as the valid grounds for employment-termination by the employer. Yet, every employment agreement implicitly requests each willing employees to be able to undertake the jobs and obligations imposed upon them. This undertaking requires them to perform their skills. Hence, a contrario is applied to Article 153 (1) (a) of UUK. The Article gives the employer justified rights to terminate employmentrelation when his or her employees are absent from their work for one year in a row, accompanied by formal doctor prescription. Whilst, on elements relating to the inability (or incompetence) to perform duty, UUK allows the employer to terminate his or her employees when they fail to: (1) undertake duty as agreed in the employment-agreement and (2) adhere to the company's regulations, even after they have been given appropriate training and workshops. ${ }^{19}$ For example, in

\footnotetext{
${ }^{17}$ Supreme Court Decision No. 658 K/Pdt.Sus/2009.

${ }^{18}$ Lilik Mulyadi, 'Pengadilan Hubungan Industrial Indonesia Dalam Kajian Perspektif Normatif, Teoritis Dan Praktik Peradilan’ (Badilum, 2007) <http://www.badilum.info/images/stories/ artikel/ pengadilan_hubungan_industrial_indonesia_dalam_kajian_perspektif_normatif_teoretis_ dan_praktik_peradilan.pdf $>$ accessed 10 August 2018 .

${ }_{19}$ Article 161, Legislation No. 13 of 2003 on Labour.
} 
the dispute between PT Bank Mega Tbk v. Henky Tetra, the Supreme Court grants justification to the employer unilateral termination as the employee has failed to achieve work targets in the amount of Rp 600.000.000/monthly. Before the termination, the employer had tried to give him warnings through a first, second, and third [or final] warning letter. The Court ordered the employer to pay the employee his entitled rights as regulated under Article 161(3) UUK, even when the employee has signed Agreements on Working Performance Improvement. The Court thinks the termination is in accordance with Article $161 \mathrm{UUK}^{20}$

On reason pertinent to indisciplines, UUK has a regulated set of actions that can be categorised as an indiscipline action. This set of actions is the only set of reasons that can be proposed by the employer to the Court for termination pertinent to indiscipline. For instance, if the employee is absent for five days work continuously without formal written notice, and that the employer had tried to sought him or her through twice written letters, then the employer can terminate him or her. This was due to the assumption the employee had resigned..$^{21}$ Also, the employer can terminate the relation when the employee had conducted criminal action so long as it has been proven based on in kracht van gewijsde. ${ }^{22}$

Several conducts can be considered as minor offense. The example of those conducts are: (1) the employees did not keep their working-utensils properly, (2) the employees are late for work, (3) the employees littered the office space, (4) the employees go home early, (5) the employees disregard the regulation on occupational and health safety. When an employer terminates employment-relation based on these minor offenses alone, the termination will be rejected. Yet, there are several instances when these minor offenses alone can be the justified grounds for termination. It is when the minor offense was done continuously despite a respective

\footnotetext{
${ }^{20}$ Supreme Court Decision No. 280 K/Pdt.Sus-PHI/2016.

${ }^{21}$ Article 168(1), Legislation No. 13 of 2003 on Labour.

22 Article 160, Legislation No. 13 of 2003 on Labour; Constitutional Court Decision No. 012/PUU 1/2003; Ministry of Labor and Transmigration Circulation Letter No. 13 of 2005 on The Application of the Constitutional Court Decision on Substantial Test Rights of Legislation No. 13 of 2003 on Labour against 1945 Constitution.
} 
letter of warnings or statement of precaution, both written and oral, ${ }^{23}$ has been sent. In the dispute between PT Bima Multifinance v. Irwan Mardianto, Medan Court of Industrial Relation justified employer unilateral termination after it is proven that previous to the termination, the employer had given chance for its employee to improve his performance through series of first, second, and third letter of warning. The warnings were sent in the hope the employee can improve his performance. Yet, as the employee failed to reach his Key Point Indicator respectively, the employer terminates and provide him his entitled compensation. ${ }^{24}$

On reason pertinent to the sake of the company's operational interests, UUK has regulated a several situations allowing the employer to terminate an employment-relation, when the situation invoved the conditions of the company, (1) a change in the merger status, (2) consolidation, (3) company acquisition, ${ }^{25}$ (4) the company is closed due to loss, compelling reasons, or for the interest of efficiency, ${ }^{26}$ and (5) bankruptcy. ${ }^{27}$ In the dispute between PT Coca Cola Bottling Indonesia v. Sri Capegiawati et al., the termination was done on the reason for company's efficiency. It was preceded by mediation between the parties. The Court ruled after the employer. ${ }^{28}$

Similar to the Convention on Termination of Employment, UUK regulated a set of reasons that may not be used by the employer for termination grounds. The reasons are: (1) the employee is absent because of sickness, not more than twelve continuous months, based on an official doctor prescription, (2) the employee cannot undertake his or her duty because of impending duty to the State, (3) religious obstacles, (4) the employee is getting married, (5) the employee is pregnant, in labour, in miscarriage, or is nursing his or her child, (6) the employee has established or is part of union labor, and et cetera. ${ }^{29}$

\footnotetext{
${ }^{23}$ Article 161, Legislation No. 13 of 2003 on Labour.

${ }^{24}$ Medan District Court on Industrial Relation Decision No. 158/Pdt.Sus-PHI/2016/PN.Mdn

${ }_{25}$ Article 163, Legislation No. 13 of 2003 on Labour.

${ }^{26}$ Article 164, Legislation No. 13 of 2003 on Labour.

${ }^{27}$ Article 165, Legislation No. 13 of 2003 on Labour.

${ }_{28}$ Supreme Court Decision No. 462 K/Pdt.Sus-PHI/2018.

${ }^{29}$ Article 153, Legislation No. 13 of 2003 on Labour.
} 
Pursuant to the description above, it can be concluded that there exists a chore requirements employer must fulfil before a termination. The requirements shall be a valid reason that was based on law, namely reasons pertinent to (1) inability, (2) indiscipline, or (3) for the sake of the company's operational interests. In other hand, reasons pertinent to human and religious rights, rights to assemble, rights to married, and rights to have a child is prohibited by the law to be used as the ground for termination by the employer.

However, the employer may not use these reasons alone to terminate an employment-relation. As had been stated supra, relying on Article 151 (1) UUK, an employer is imposed for a duty of care to prevent any employment-termination in the best of their abilities. In elaboration, prevention can be pursued through a set of positive activities such as regulation on working days and hours, efficiency, an improvement on ways of working, and to give training [or workshops] to the employee. This provision was further reinforced by the Ministry for Labour Circulation Letter No. 907 of 2004 on Prevention on Mass Employment Termination. The Letter appeal that, to every company entangled with difficulties, in which the difficulties may negatively impact its labor, termination of employment shall only be the last resort after means such as: (1) decreasing working-days and workinghours, (2) decreasing or deleting over hours, (3) decreasing the amount of payment and facilities for the manager and director, (4) ceasing relation with employee whose time is close to end, and (5) granting superannuation to employee that has fulfilled the requirements, has been done.

Clearly, the employer duty of care to prevent was a form of employee's protection against arbitrariness. Regulation regarding employment security is the chore means that protects the employee's income security. ${ }^{30}$ Employmenttermination threatens the employee's life continuity. On another hand, when the employee breached provision agreed in an employment agreement, the employer may not unilaterally terminate their relation. But the rule can be excluded when

${ }^{30}$ Sukti Dasgupta, Employment Security: Conceptual and Statistical Issues (International Labour Office 2001).[6]. 
the pertinent employee had not yet been given letter of warnings previous to his or her termination.

Provision on Article 151(1), supra, implicitly gives responsibility to the employer, regarded as the party that manages the company to be one who needs to endeavor in the best in their abilities to prevent continuous loss to the company. A continuous loss may result in massive employment-termination. Hence, for reasons pertinent to the sake of the company operational interests, taking in consideration of the workers protection, the employer own the responsibility to pursue, endeavour, all possible means to prevent employment-termination.

Additionally, the Article also burdened the employer to give the lacking employee a chance to improve their working performance. Minor offenses cannot be used as the ground for straight employment-termination. It must first be preceded by letter of warnings, as warnings are a form of more humane training that gave the directed employee a chance to improve their skills, behaviour, and working performance with the objectives the employee will not repeat his or her mistake again. As what has been prescribed by Article 161 UUK that in the event the employee breached terms in the employment-agreement, the employer can terminate him or her, after the pertinent employee is given first, second, and the third letter of warnings respectively. Letters of warning, as what was elaborated within paragraph (1), apply for a maximum of six months, unless decided otherwise in the agreement. An employee that is terminated based on these reasons shall receive a single severance based on Article 156 (2), singe appreciation payment based on Article 156 (3), and single substitution payment based on Article 156 (4).

Nevertheless, the duty of care to prevent is excluded when the employee has conducted a criminal act. This can be found in provision within Article 160 (3), (5), (6), and (7) of UUK that state, an employer can terminate an employmentrelation if, after six months he or she is unable to carry his or her duty as he or she was involved in a criminal proceedings, the unilateral termination by the employer thus justified. Termination based on this reason need not decision from the Court of Industrial Relation. But, even if the termination was based on this reason, the 
employee is still entitled to appreciation and rights-substitution payment as per regulated within Article 156 (3) and (4) of UUK.

For example, the dispute between Koperasi Simpan Pinjam Dian Mandiri v. Sherley Malawau. The employer terminates its employee after the employee is proven to have conducted a criminal act of embezzlement, punished for ten months imprisonment, based on Cibinong District Court Decision No. 260/Pid.B/2015/PN Cbi. However, the employee refuses to accept the employer's actions and propose her complain to the Court of Industrial Relation at Serang District Court after mediation between the parties had been conducted. After going through continuous proceedings, the Judge decides the unilateral employment-termination by the employer is valid as it was based on in kracht van gewijsde. ${ }^{31}$ On the cassation level, the decision was reinforced by the Supreme Court. ${ }^{32}$

Another example was the dispute between PT SMART Tbk v. Edy. The employer conducted an unilateral employment-termination after its employee was proven to have conducted major offense that was theft. ${ }^{33}$ Following the decision, the employer act was then validated by Medan District Court on Industrial Relation through Decision No. 61/ Pdt-Sus-PHI/2014/PN.Mdn on 29 September 2014. In further assessment, the decision was reinforced by Supreme Court decision No. 763K K/Pdt/Sus-PHI/2014 on 30 March 2015.

Both the Court decisions above re-state that in the event of employmenttermination, the employer's duty of care can be excluded. The employer may terminate the employee unilaterally for reasons that the employees has failed to undertake their duty for six months, because the pertinent employees is involved in criminal proceedings, or because the employees have been proved to have conducted criminal act by the Court before the six months terms ended. Again, this exclusion was based on Article 151 (1) of UUK. An employee involved in a criminal proceeding more than six months or even after being ruled guilty on a criminal act, will be no longer under the care or responsibility of his or her employer.

\footnotetext{
${ }^{31}$ Serang District Court of Industrial Relation No. 115/Pdt.Sus-PHI/2016/PN. Srg.

32 Supreme Court Decision No. 991 K/Pdt-Sus-PHI/2017.

${ }^{33}$ Rantauprapat District Court Decision No. 67/Pid.C/2014/PN-RAP.
} 
The provisions supra is in accordance with International Labor Convention No. 158 of 1982 on Termination of Employment based on the Employer Initiatives. Within Article 11 of the Convention, a worker whose employment is to be terminated shall be entitled to a reasonable period of notice or compensation in lieu thereof, unless he is guilty of serious misconduct, that is, misconduct of such a nature that it would be unreasonable to require the employer to continue his employment during the notice period. In several European Union States, when an employee has conducted a criminal act or is unavailable due to force majeure, ${ }^{34}$ the employer is not obligated to give notice. It is an unreasonable demand to sue the employer to continue the employment-relation with the employee during the notification period.

\section{Conclusion}

Employer's duty of care to prevent termination of employment in accordance with Article 151 (1) UUK can be excluded when the reason for the termination was because the employee has failed to undertake his or her duty for more than six months due to their involvement in criminal proceedings. If the Court decides the matter before the six months term ended and the employee is proven to be guilty, the employer may unilaterally terminate the pertinent employee. An employee involved in a criminal proceeding (more than six months), or even after being ruled guilty of a criminal act, will be no longer under the care or responsibility of his or her employer.

\section{Bibliography}

A.C.L Davies, Perspectives on Labour Law (Cambridge University Press 2004).

Aloysius Uwiyono dkk, Asas-Asas Hukum Perburuhan (Rajagrafindo Persada 2014).

Ashgar Ali Ali Mohamed, 'Resolution of Industrial Disputes in New Zealand' (2012) 2 International Journal of Humanities and Social Science.

${ }^{34}$ Directorate General Employment Social Affairs and Equal Opportunities, 'Termination of Employment Relationships: Legal Situation in the Member States of the European Union' (European Commission, 2006) <https://ec.europa.eu/social/BlobServlet?docId=4623\&langId=en $>$ accessed 10 August 2018.[3]. 
Bob Hepple, 'A Right to Work' (1981) 10 Industrial Law Journal.

Constitutional Court Decision No. 012/PUU 1/2003; Ministry of Labor and Transmigration Circulation Letter No. 13 of 2005 on The Application of the Constitutional Court Decision on Substantial Test Rights of Legislation No. 13 of 2003 on Labour against 1945 Constitution.

Deden Muhamad Surya, 'Pemutusan Hubungan Kerja Akibat Menolak Mutasi Ditinjau Dari Perspektif Asas Kepastian Hukum Dan Asas Keadilan' (2018) 2 Jurnal Wawasan Yuridika.

Directorate General Employment Social Affairs and Equal Opportunities, 'Termination of Employment Relationships: Legal Situation in the Member States of the European Union' (European Commission, 2006) <https:// ec.europa.eu/social/BlobServlet?docId=4623\&langId=en $>$ accessed 10 August 2018.

ILO Declaration of Philadelphia 1944 concerning the Aims and Purpose of the International Labour Organisation.

ILO Convention No. 158 of 1982 on Termination on Employment based on the Employer Initiatives.

Indi Nuroini, 'Penerapan Perjanjian Bersama Dalam Pemutusan Hubungan Kerja' (2015) 8 Jurnal Yudisial.

Legislation No. 13 of 2003 on Labour.

Lilik Mulyadi, 'Pengadilan Hubungan Industrial Indonesia Dalam Kajian Perspektif Normatif, Teoritis Dan Praktik Peradilan' (Badilum, 2007) <http:// www.badilum.info/images/stories/artikel/ pengadilan_hubungan_industrial_ indonesia_dalam_kajian_perspektif_normatif_teoretis_dan_praktik_ peradilan.pdf $>$ accessed 10 August 2018 .

Manado District Court of Industrial Relation Decision No. 22/G/2012/PHI.MDO.

Medan District Court on Industrial Relation Decision No. 158/Pdt.Sus-PHI/2016/PN.Mdn.

Ministry for Labour Circulation Letter No. 907 of 2004 on Prevention on Mass Employment Termination.

Mohammad Ilyas, 'Pengambilalihan Dan Penutupan Perusahaan Yang Berdampak Pada Perselisihan Pemutusan Hubungan Kerja Menurut Undang-Undang Nomor 13 Tahun 2003 Tentang Ketenagakerjaan' (2018) 3 Jurnal Ius Constituendum. 
Rantauprapat District Court Decision No. 67/Pid.C/2014/PN-RAP.

Robert C. Byrd, 'Employment as A Relational Contract' (2005) 8 Journal of Labor and Employment Law.

Serang District Court of Industrial Relation No. 115/Pdt.Sus-PHI/2016/PN. Srg.

Supreme Court Decision No. 658K/Pdt.Sus/2014.

Supreme Court Decision No. 280 K/Pdt.Sus-PHI/2016.

Supreme Court Decision No. 991 K/Pdt-Sus-PHI/2017.

Supreme Court Decision No. 462 K/Pdt.Sus-PHI/2018.

Supreme Court Decision No. 658 K/Pdt.Sus/2009.

Simon Deakin and Wanjiru Njoya, 'The Legal Framework of Employment Relations, Working Paper No. 349’ (2007).

Sukti Dasgupta, Employment Security: Conceptual and Statistical Issues (International Labour Office 2001).

HOW TO CITE: Budi Santoso, 'Juridical Analysis on Entrepreneurs' Obligation of Effort to Prevent Termination of Employment' (2020) 35 Yuridika. 
--This page is intentionally left blank-- 